\title{
The FASB's Concepts Statement On Cash Flows And Present Value
}

Stanley Martens (E-mail: smartens@depaul.edu), DePaul University

Thomas Berry, DePaul University

\begin{abstract}
In February 2000, the Financial Accounting Standards Board (FASB) issued Statement of Financial Accounting Concepts No. 7, Using Cash Flow Information and Present Value in Accounting Measurements. In this document the FASB asserts without proof that a present value computation along its lines will provide a good estimate of the fair value of an asset or liability. Using numerical examples provided by the FASB, we attempt to construct arguments in support of the FASB's claim. We find that such arguments require strong and not at all obvious assumptions about players in hypothetical markets.
\end{abstract}

$T$

he Financial Accounting Standards Board (FASB) sets accounting standards in the U.S. for businesses and nonprofit nongovernmental entities. The FASB issues accounting standards in the form of Statements of

Financial Accounting Standards (FASs). Another type of document that the FASB issues are Statements of Financial Accounting Concepts (CONs). Although CONs do not set accounting standards, they are intended to guide the FASB in its promulgation of future standards. In the period from November 1978 through December 1985 the FASB issued six CONs. It is true, although it will not be argued here, that much of the FASB's standard-setting work since 1985 can be seen as implementation of the agenda set out in the first six CONs. We only state this point to indicate that the issuance of a CON is important for future standards-setting by the FASB.

In February 2000, the FASB issued Statement of Financial Accounting Concepts No. 7, Using Cash Flow Information ad Present Value in Accounting Measurements. According to the FASB, the point of computing present value is to estimate the fair value of an asset or liability. The essence of the FASB's approach is given in paragraph 39 and 40 of CON 7:

39. Paragraph 23 describes the following elements that together capture the economic differences between various assets and liabilities: ${ }^{7}$

a. An estimate of the future cash flow, or in more complex cases, series of future cash flows at different times

b. Expectations about possible variations in the amount or timing of those cash flows

c. The time value of money, represented by the risk-free rate of interest

d. The price for bearing the uncertainty inherent in the asset or liability

e. Other, sometimes unidentifiable, factors including illiquidity and market imperfections.

( ${ }^{7}$ The effect of the entity's credit standing on the measurement of its liabilities is discussed in paragraphs 75-88.)

Readers with comments or questions are encouraged to contact the authors via email. 
40. This Statement contrasts two approaches to computing present value, either of which may be used to estimate the fair value of an asset or a liability, depending on the circumstances. In the expected cash flow approach discussed in this Statement, only the third factor listed in paragraph 39 (the time value of money, represented by the risk-free rate of interest) is included in the discount rate; the other factors cause adjustments in arriving at risk-adjusted expected cash flows. In a traditional approach to present value, adjustments for factors (b) - (e) described in paragraph 39 are embedded in the discount rate.

What CON 7 lacks is any argument to support that a present value computation involving the five elements is a good estimate of fair value. All the CON contains is an assertion that such a computation approximates fair value (paragraph 24a):

Fair Value captures all five elements using the estimates and expectations that marketplace participants would apply in determining the amount at which that asset (or liability) could be bought (or incurred) or sold (or settled) in a current transaction between willing parties.

The FASB's claim is only asserted and not supported by any argument. We believe that we can construct such arguments, using the numerical examples that the FASB gives in Appendix A of the CON. The resulting arguments require certain strong assumptions about the players in the hypothetical market which determines fair value. Hence, our criticism of the FASB will boil down to the following:

The FASB merely asserts, and does not demonstrate, that a present value computation along its lines will result in a good estimate of fair value. The only arguments that we can think of to tie the FASB-style present value calculation to fair value involve strong assumptions that are not at all obvious about players in hypothetical markets. We will see that this problem is especially acute with respect to the fair value of liabilities.

Let us proceed with constructing arguments that the FASB failed to construct.

Appendix A of CON 7 contains illustrations of present value computations for five assets and one liability. We will focus on one of the five assets (Asset D) and the liability (a liability for site reclamation to be performed in the future).

Asset D is described as follows (paragraph 110 of CON 7):

Asset D: $\quad$ An asset with a fixed contractual cash flow of $\$ 10,000$ due in 10 years.

The amount that ultimately will be received is uncertain. It may be less than $\$ 10,000$ but will not be more.

The FASB further supposes that the rate of interest for 10-year default risk-free assets is 5\%, and that the firm making the promise to pay (we will call this firm F1) has an .8 probability of paying the $\$ 10,000$ and a .2 probability of defaulting with $\$ 0$ recovery possible (these suppositions can be found in paragraph 113).

The FASB's present value computation can be found in paragraph 115:

$\begin{array}{lc} & \begin{array}{l}\text { Asset D } \\ \text { Uncertain } \\ \text { Contractual (promised) cash flow }\end{array} \\ \text { Adjustment to reflect expectations } & \underline{\$ 10,000} \\ \text { Expected cash flow } & \underline{(2,000)} \\ \text { Adjustment to reflect risk premium } & \underline{(500)} \\ \text { Adjusted cash flows } & \underline{\underline{\$ 7,500}} \\ \text { Present value at } 5 \text { percent (risk-free rate) } & \underline{\$ 4,604}\end{array}$


The following is an argument that a hypothetical purchaser (call such a purchaser firm F2) will pay $\$ 4,604$ for Asset D in a hypothetical market, i.e., the $\$ 4,604$ is the fair value of Asset D.

The first assumption that has to be made to get the argument going is that if F2 does not pay F1 for its promise, then the next best alternative use of the funds which would have been used to pay F1 would be to invest in a default risk-free investment yielding 5\%. (We must disregard a possible F2 shareholder objection that any such investment is a poor use of the funds.) The second assumption is that there is a utility function for firm F2. If payment (p) is to be made by F2 to F1 instead of p being invested in a default risk-free investment, then the utility of $\mathrm{p}(1.05)^{10}$ must be less than or equal to the expected utility of $\$ 10,000$ ten years hence. Since the probability of F1's paying the $\$ 10,000$ is $.8, \mathrm{U}\left(\mathrm{p}(1.05)^{10}\right) \leq .8 \mathrm{U}(\$ 10,000)$.

The highest that the payment $\mathrm{p}$ can be set is such that $\mathrm{U}\left(\mathrm{p}(1.05)^{10}\right)=.8 \mathrm{U}(\$ 10,000)$. If $\mathrm{F} 2$ is risk-neutral, the utility function can be expressed as multiplication by a constant, and the payment will be $\mathrm{p}=.8(\$ 10,000) /(1.05)^{10}=$ $\$ 8,000 /(1.05)^{10}=\$ 4,911$. If $F 2$ is risk-averse, the payment $\mathrm{p}$ will be lower than $\$ 4,911$. How much lower? The third assumption must be that $\mathrm{F} 2$ is risk-averse to the extent that $\mathrm{U}(\$ 7,500)=.8 \mathrm{U}(\$ 10,000)$. Then, $\mathrm{p}(1.05)^{10}=$ $\$ 7500$, or $\mathrm{p}=\$ 7,500 /(1.05)^{10}=\$ 4,604$, as the FASB desires. ${ }^{1}$

The preceding argument makes strong assumptions about a hypothetical player (F2) in a hypothetical market for F1's promise: assumptions about the next best use of F2's funds, the existence of a utility function for F2, and the risk-aversion exemplified by such a utility function. ${ }^{2}$

Let us now turn to the liability example in Appendix A, paragraph 118. The liability is for site reclamation 10 years hence. Call the entity bearing the liability E Co. The FASB supposes that E Co. will hire a contractor (call the contractor $\mathrm{C}$ ) ten years hence to perform the work. The expected bill that $\mathrm{C}$ will present $\mathrm{E}$ with 10 years hence is $\$ 415,209$. The FASB also supposes that the expected costs to C ten years hence are $\$ 366,360{ }^{3}$ The default risk-free rate of interest is again 5\%.

The FASB's calculation of present value of the liability is in the exhibit in paragraph 118:

\begin{tabular}{lr} 
Expected cash flows & $\$ 415,209$ \\
Market risk premium & 42,000 \\
Credit Discount & $\underline{(133,830)}$ \\
Expected cash flows, adjusted for risk & $\underline{\$ 323,379}$ \\
\hline
\end{tabular}

Present value at 5 percent (risk-free rate) $\$ \underline{\underline{\$ 198,527}}$

The following is an argument that a hypothetical contractor C will accept \$198,527 from E now for doing the work 10 years hence. We assume that there is only one possible amount of costs that $\mathrm{C}$ will pay entirely in cash 10 years hence $(\$ 366,360)$ and only one possible bill that $C$ would offer $E 10$ years hence if $C$ does not accept cash now $(\$ 415,209)$. This assumption is made only to simplify the algebra in what follows. ${ }^{4}$ Another assumption, one that is crucial to the argument, is that C's alternatives are to accept payment from E now, invest the proceeds in riskfree investments, and do the work ten years hence, or do the work ten years hence and bill $\mathrm{E}$ then. A second crucial assumption is that a utility function exists for $\mathrm{C}$. Let $\mathrm{d}_{\mathrm{E}}$ be the probability that $\mathrm{E}$ will inevocably default on the bill ten years hence. The payment $(\mathrm{p})$ that $\mathrm{E}$ should make today is determined by the following formula involving C's utility function:

$\mathrm{U}\left(\mathrm{p}(1.05)^{10}-\$ 366,360\right)=\left(1-\mathrm{d}_{\mathrm{E}}\right) \mathrm{U}(\$ 415,209-\$ 366,360)+\mathrm{d}_{\mathrm{E}} \mathrm{U}(-\$ 366,360)$.

If $C$ is risk-neutral, $\mathrm{p}(1.05)^{10}=\left(1-\mathrm{d}_{\mathrm{E}}\right) \$ 48,849+\$ 366,360-\mathrm{d}_{\mathrm{E}} \$ 366,360$

$$
\begin{aligned}
& =\left(1-d_{E}\right)(\$ 48,849+\$ 366,360) \\
& =\left(1-d_{E}\right)(\$ 415,209)
\end{aligned}
$$


Since the FASB identifies $\$ 133,830$ as the "credit discount" related to E's credit standing (and hence to E's probability of defaulting $),\left(1-d_{E}\right)=(\$ 415,209-\$ 133,830) / \$ 415,209=\$ 281,379 / \$ 415,209=.678$. So, risk-neutral $p$ $=\$ 281,379 /(1.05)^{10}=\$ 172,742$. If $\mathrm{C}$ is risk averse, $\mathrm{p}$ may be greater than $\$ 172,742$, since negative cash flows are involved. The third crucial assumption must be that $\mathrm{C}$ is risk-averse to the extent that $\mathrm{U}(-\$ 42,980)=.678 \mathrm{U}(\$ 48,849)$ $+.322 \mathrm{U}(-\$ 366,360)$. Then, $\mathrm{p}(1.05)^{10}-\$ 366,360=-\$ 42,980$, and $\mathrm{p}=\$ 323,380 /(1.05)^{10}=\$ 198,527$, as the FASB desires.

As with the argument we constructed for the asset example, the argument we have just presented makes strong assumptions about a hypothetical market player. In this case, the hypothetical market player is a contractor (C), and the assumptions include suppositions about what $\mathrm{C}$ would do with prepayment funds, the existence of a utility function for $\mathrm{C}$, and the risk-aversion associated with such a utility function.

In a section of CON 7 entitled "Credit Standing and Liability Measurement" (paragraphs 78-88), the FASB makes the controversial claim that "the most relevant measure of a liability always reflects the credit standing of the entity obligated to pay" (paragraph 78). In the argument we have just presented for the liability case, E's credit standing can be taken to be relevant if it is assumed that E's credit standing determines $\mathrm{d}_{\mathrm{E}}$, the probability that $\mathrm{E}$ will irrevocably default on a bill for site reclamation ten years hence.

There are liabilities of different kinds than the one we have just considered for which an entity's credit standing does not determine the probability of the entity's defaulting. Hence, the FASB's claim is unjustified.

As an example of a liability for which credit standing does not determine default probability, consider the projected benefit obligation for defined benefit pension plans. Per U.S. GAAP (Generally Accepted Accounting Principles) this amount is disclosed in the notes to the financial statements but not recorded. The amount of the projected benefit obligation according to current GAAP is computed using a present value computation, but that computation does not reflect the credit standing of the company with the defined benefit pension plan. ${ }^{5}$

The probability that a U.S. company will default on its future pension payments to retirees will not be determined by its credit standing, because U.S. law contains requirements and incentives that cause pension plans to be prefunded. White, Sondhi, and Fried (1994, p.635) state the following:

In the United States, pension plans are virtually always funded because of the requirements of the Employee Retirement Income Security Act of 1974 (ERISA) and tax advantages, including tax deductibility of the employer's contribution and tax-exempt status of earnings on fund investments. Outside the United States, pension obligations are often unfunded.

Because pension plans in the U.S. are prefunded and not "pay as you go", two companies A and B may have different credit standings, but the same probability of default on their future pension payments to retirees. It is not necessarily true that if A has a higher credit standing than B, then B's probability of defaulting on pensions is higher than A's. A and B may have pension plans funded at the same level.

The FASB has a response to these considerations concerning pension obligations, but it is not a very good one (paragraphs 84 and 85 ):

...(Some) suggest a measurement approach in which financial statements would portray the present value of an obligation such that two entities with the same obligation but different credit standing would report the same carrying amount. Some existing accounting pronouncements take this approach, most notably FASB Statement No. 87, Employers' Accounting for Pensions, and No. 106, Employers' Accounting for Postretirement Benefits Other Than Pensions...However, there is no convincing rationale for why the initial measurement of some liabilities would necessarily include the effect of credit standing (as in a loan for cash) while others might not (as in a warranty liability or similar item)... 
What the FASB fails to see is that there is a rationale for why the measurement of the projected benefit obligation does not include the effect of credit standing: credit standing does not determine the probability of default on future pension payments when those payments are prefunded.

\section{References}

1. Financial Accounting Standards Board (FASB). 1996. Current Text: Accounting Standards as of June 1, 1996. Volume I. New York, NY: John Wiley \& Sons, Inc.

2. _. February 2000. Using Cash Flow Information and Present Value in Accounting Measurements. Statement of Financial Accounting Concepts No. 7. Norwalk, CT: FASB.

3. White, G., Sondhi, A., and Fried, D. 1994. The Analysis and Use of Financial Statements. New York, NY: John Wiley \& Sons, Inc.

\section{End Notes}

1 "Adjustment to reflect risk premium" is given in the FASB's present value computation as $\$ 500$. This is simply the future value at $5.00 \%$ and 10 years of the difference between risk-neutral $\$ 4,911$ and risk-averse $\$ 4,604 ; \$ 4,911$ - $\$ 4,604=\$ 307$ and $\$ 307(1.05)^{10}=\$ 500$. So, the FASB's mathematical treatment of risk-aversion is not incorrect. What the FASB says about risk-aversion, however, is questionable. In paragraph 114, the FASB states, "As mentioned in paragraphs 62-74, marketplace participants typically seek compensation for accepting uncertainty." Hence, according to the FASB, the \$307 is "compensation" to F2. Why is the compensation set at \$307 instead of at some higher level commensurate with "what the market traffic will bear"? What would make the compensation fair? It seems that if the $\$ 307$ does not represent risk aversion by F2, it is simply a profit element.

${ }^{2}$ We will not construct similar arguments for Assets A,B,C, and E in Appendix A. The reader can construct them; suffice it to say that the formulas for setting price involving the utility function of F2 are as follows:

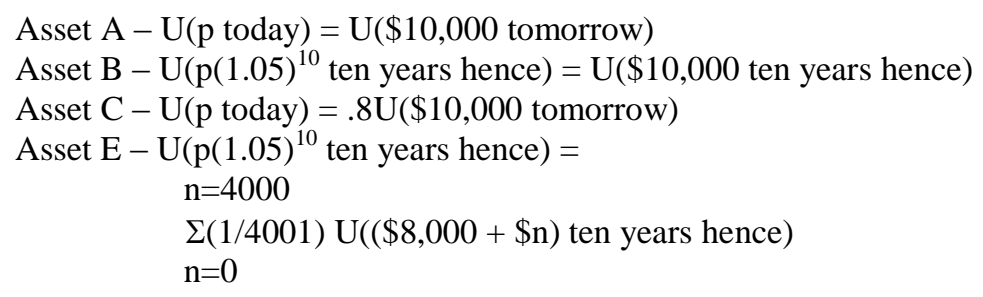

3 The $\$ 366,360$ can be tied out to the numbers in the exhibit in paragraph 117 as follows: $\$ 280,500$ $\$ 33,000)(1.04)^{10}=\$ 366,360$.

${ }^{4}$ In the example as given by the FASB, the $\$ 415,209$ is not the single possible bill that $\mathrm{C}$ gives $\mathrm{E}$ ten years hence. Rather, the $\$ 415,209$ is the expected amount of a number of possible bills. Also, the $\$ 366,360$ is the expected amount of a number of possible total costs. The formula giving the conditions on C's utility function would be unduly complex if we took into account all the possible bills and costs and their probabilities. Such complexification would not materially effect the argument.

${ }^{5}$ Refer to the Current Text (FASB 1996), Section P16, paragraph 138 for current GAAP on the selection of the discount rate for calculating the projected benefit obligation. 
Notes 